\title{
Effect of azadirachtin on the hemolymph protein of the adult desert locust, Schistocerca gregaria (Forskal) (Orthoptera: Acrididae)
}

\author{
Dalia M. Mahmoud $^{\mathbf{1}^{*}}$, Thoryia F. K. Elnaggar ${ }^{1}$, Hoda M. Abdel Fattah ${ }^{\mathbf{1}}$ and Amal F. Abdel Kader ${ }^{2}$ \\ ${ }^{1}$ Department of Entomology, Faculty of Science, Ain Shams University, Abbasia, Cairo, Egypt \\ 2 Department of Botany, Faculty of Science, Ain Shams University, Abbasia, Cairo, Egypt
}

A R T I C LE IN F O

Article history:

Received 30 September 2014

Accepted 06 November 2014

Keywords:

Azadirachtin;

hemolymph protein;

electrophoresis;

Schistocerca gregaria.

\begin{abstract}
A B S T R A C T
Azadirachtin is a botanical insecticide affects a variety of biological processes of insects. Effect of azadirachtin on the hemolymph protein of 7 days old adult locust, Schistocerca gregaria was studied in this work. Through intersegmental membrane between the third and fourth abdominal tergite, Schistocerca gregaria was injected with the three chosen doses of azadirachtin $(7.5-15-30 \mu \mathrm{g} / \mathrm{g}$ body weight). After $24 \mathrm{~h}$ post injection, the hemolymph protein of the treated and control (untreated) insects were fractionated by SDS polyacrylamide gel electrophoresis (PAGE). The results revealed that, total amount percentage of protein patterns between treated and untreated hemolymph generally decreased due to treatment course and there are three protein bands appeared (18- 45 and $72 \mathrm{kDa}$ ) due to treatment course with three doses of azadirachtin. Azadirachtin might interfere with hemolymph protein in desert locust, Schistocerca gregaria.
\end{abstract}

\section{Introduction}

Azadirachtin obtained from the neem tree (Azadirachta indica). It was considered as one of the most important bioinsecticide in the world. It was less harmful to environment and human and biodegradable by sunlight. It was more advantageous than synthetic insecticide, which has extreme persistent and bioaccumulation. Azadirachtin can be recommended for many integrated pest management (IPM) ${ }^{[\mathbf{1 , 2}]}$. Azadirachtin has an adverse effect on more than 400 insect species. It has antifeedant effect ${ }^{[1,3,4]}$ has affected pest growth by disruption of hormones that control moulting and metamorphosis ${ }^{[5]}$, it has repellence effect ${ }^{[6]}$, oviposition deterrence $^{[7]}$, direct toxicity ${ }^{[8]}$, feeding deterrence ${ }^{[9]}$ and cause anatomical abnormalities for several insect pests ${ }^{[10]}$.

Desert locust, Schistocerca gregaria (Forskal) (Orthoptera: Acrididae) is considered as one of the most dangerous insect pests. It occurs in Northern Africa, Peninsula and Southwest Asia ${ }^{[11]}$. Locusts begin as a solitary phase which has no economic importance but due to food competition it changes from solitary to gregarious phase which has large economic importance $[12,13]$

In the present study we attempt to study the effect of azadirachtin on hemolymph protein profile of adult locust, Schistocerca gregaria as a step in control adult

* Corresponding author.

E-mail address: daliamohamad@ rocketmail.com

\section{locusts by neem.}

\section{Materials and methods}

\section{1- Insect rearing}

Crowded (gregarious) adults of Schistocerca gregaria $(S$. gregaria) were collected from Cairo governorate, Egypt. The colony were reared in wooden cages for three generations at $30 \pm 2{ }^{\circ} \mathrm{C}$ and relative humidity $(70-80 \%)$ under a 12:12 h light: dark regime. The insect were fed on Sesbania aegyptiaca, which is freshly supplied daily. Suitable pots for oviposition were put in the cages, examined daily to remove pots that contain eggs into another cage. After three generations, 7 days old adult locusts were used for the experiments. The age of locusts was 7 days after final ecdysis because this represents the peak of protein synthesis according to ${ }^{[14]}$.

\section{2- Extraction and treatment with azadirachtin}

Azadirachtin were obtained from neem seeds ${ }^{[15]}$ and purified chromatographically according to ${ }^{[\mathbf{1 6}]}$ by HPLC to get final concentration of azadirachtin $(1 \mathrm{mg} / \mathrm{ml})$. Azadirachtin was dissolved in $10 \%$ ethanol in selected concentrations to comprise the desired doses $(7.5,15$ and $30 \mu \mathrm{g} / \mathrm{g}$ body weight) according to ${ }^{[4]}$. Each of these doses was injected, through the dorsolateral area of the intersegmental membrane between the third and fourth abdominal tergite into the adult of $S$. gregaria.

Control insects were injected with the same doses of $10 \%$ ethanol/g body weight by $25 \mu \mathrm{l}$ syringe.

After $24 \mathrm{~h}$ post injection the hemolymph samples were collected from the base of the hind coxa of the insect by 
$5 \mu 1$ micropipette.

Hemocytes were removed by centrifugation at 12,000 r.p.m. for $15 \mathrm{~min}$., the supernatant (plasma) was removed from hemocytes pellet into another tube and stored at $-18^{\circ} \mathrm{C}$ until use.

\section{3- Protein electrophoresis}

Hemolymph proteins were fractionatd by SDS polyacrylamide gel electrophoresis (PAGE) as described by ${ }^{[17]}$ modification method. The hemolymph samples were prepared by mixing the sample with $\beta$ mercaptoethanol, glycerol, SDS and bromophenol blue and heating the mixture in boiling water bath for $4 \mathrm{~min}$ to denature the proteins. The gel was run at a constant voltage $100 \mathrm{~V}$ for $4 \mathrm{~h}$ at room temperature. The electrophoretic protein profiles of hemolymph for both control and treated adults were done along with wide range protein marker by disc electrophoresis on $10 \%$ polyacrylamide gel after $24 \mathrm{~h}$ post injection. The gel was scanned with gel documentation system by using a scanner (Scan tack, Sport Technology) and then, the bands were analyzed by using software: Gel-Pro Analyzer, version 3.1 for windows 95/NT, from Media Cybernetics (1993-1997) U.S.A.

\section{Results}

Hemolymph proteins of 7 days old adult locust, $S$. gregaria control and treated with three doses of azadirachtin ( $(7.5,15$ and $30 \mu \mathrm{g} / \mathrm{g}$ body weight), were analyzed after $24 \mathrm{~h}$ of treatment. Changes in the hemolymph proteins of treated and control adults are presented in Fig. 1 as well as in Tables 1 and 2. Characterization of hemolymph proteins detected a total 10 protein bands in control pattern and 11 protein bands in treated patterns with $7.5 \mu \mathrm{g} / \mathrm{g}$ body weight azadirachtin, 8 protein bands in hemolymph treated with dose $15 \mu / \mathrm{g}$ body weight of azadirachtin, and 10 protein bands in hemolymph treated with $30 \mu \mathrm{g} / \mathrm{g}$ body weight of azadirachtin. The molecular weight of total protein bands in treated and control samples were ranged from $(11-140 \mathrm{kDa})$.

A change could be detected in hemolymph protein patterns of treated with $7.5 \mu \mathrm{g} / \mathrm{g}$ body weight when compared with control, where 3 protein bands were disappeared due to treatment with azadirachtin (11- 16.6 and $86.8 \mathrm{kDa}$ ).

On other side, 4 new protein bands were specific to treatment with azadirachtin $(18.5,45,72$ and $120 \mathrm{kDa})$. Seven protein bands were common between treated and control hemolymph $(15,23.6,25.4,58,65.4,108.5$ and $140 \mathrm{kDa}$ ). Three of them were increased in their amount percentage due to treatment (58- 108.5 and 140 $\mathrm{kDa}$ ) by $2.8,16.6$ and 1.1 folds, respectively. The other four protein bands $(15,23.6,25.9$ and $65.4 \mathrm{kDa})$ were decreased in their amount percentage by 2.3, 2.6, 2 and 3.2 folds, respectively.

Comparing control hemolymph protein patterns and the treatment with $15 \mu \mathrm{g} / \mathrm{g}$ body weight azadirachtin, it was observed a disappearance of 4 protein bands $(15,25.4$, 86.8 and $140 \mathrm{kDa}$ ) and appearance of 3 new protein bands due to treatment $(18,45$ and $72 \mathrm{kDa})$ with protein amount percentage (1.2, 7.9 and $7.3 \%)$, respectively. Five common protein bands were detected between treated and control $(11,16.6,23.6,16.6$ and $11 \mathrm{kDa})$ all of them were decreased in their amount percentage by $(1.3,5.8,1.1$ and 2.7 folds), respectively except $58 \mathrm{kDa}$ was increased by 3 folds.

Injection with $30 \mu \mathrm{g} / \mathrm{g}$ body weight azadirachtin showed a disappearance of 4 protein bands $(15,23.6,86.8$ and $140 \mathrm{kDa}$ ) and appearance of new 4 new protein bands $(18,45,72$ and $140 \mathrm{kDa})$ with amount percentage $(2.5$, 9.7, 10.6 and $4.3 \%$ ), respectively, as compared to control. Six common protein bands were detected between treated and control (11, 16.6, 25.4, 58, 65.4 and $108.5 \mathrm{kDa}), 4$ of them $(11,16.6,25.4$ and 65.4 $\mathrm{kDa}$ ) were decreased in their amount percentage by 5.1 , 24.6, 2.6 and 1.1folds, respectively except 58 and 108.5 $\mathrm{kDa}$ which was increased in amount percentage by 3.1 and 8.7 folds, respectively.

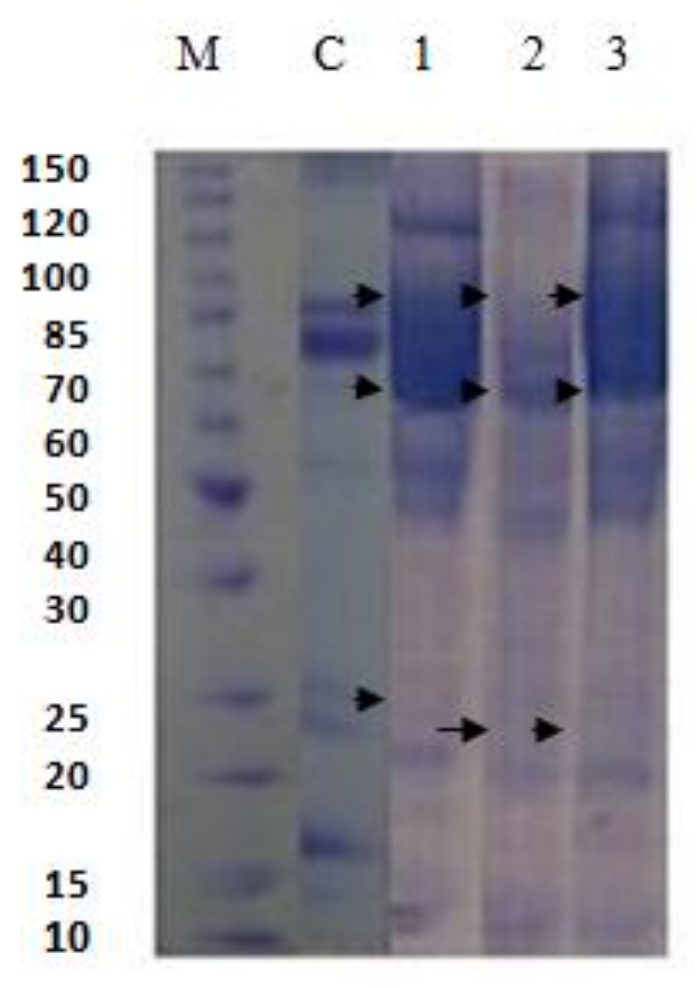

Fig (1): Photograph illustration of electrophoretic hemolymph protein patterns of treated and control adults of $S$. gregaria. $\mathrm{M}=$ wide range protein marker $(150,120,100,85,70,60,50,40,30,25$, and 15 $\mathrm{kDa})$. Lane $\mathrm{C}=$ control. Lanes 1,2 and $3=$ treated hemolymph protein patterns with $(7.5,15$ and 30 $\mu \mathrm{g} / \mathrm{g}$ body weight of azadirachtin), respectively.

\section{Discussion}

Proteins play an important role in the cell such as hormonal regulation. They act as structural element as carbohydrates and lipids ${ }^{[18,19]}$. In addition, protein synthesis is necessary for maintenance of body growth and reproduction ${ }^{[20]}$. Azadirachtin affected pest growth by disruption of hormones that control moulting and metamorphosis ${ }^{[3,4]}$. 
The results reported in this paper of the protein expression in 7 days old adult $S$. gregaria with and without treatment with azadirachtin, showed that when adult locusts injected with three doses of azadirachtin (7.5, 15 and $30 \mu \mathrm{g} / \mathrm{g}$ body weight), the results were shown that in low dose $7.5 \mu \mathrm{g} / \mathrm{g}$ body weight, the total number of protein bands were slightly increased from 10 protein bands for control to 11 protein bands in treated pattern. By increasing dose of azadirachtin to $15 \mu \mathrm{g} / \mathrm{g}$ body weight, number of protein bands were decreased from 10 to 8 due to treatment and not changed by increasing the injected azadirachtin dose to $30 \mu \mathrm{g} / \mathrm{g}$ body weight. Generally the protein expression in treated adult $S$. gregaria was decreased due to azadirachtin treatment. This result was agreed with the results of ${ }^{[20,21]}$, they shown that protein expression can be lowered by exposing insects to diet containing azadirachtin or injecting larvae with it. In addition by treatment with (7.5, 15 and $30 \mu \mathrm{g} / \mathrm{g}$ body weight) of azadirachtin. 3,4 and 4 protein bands were disappeared, and 3 new protein bands were appeared in hemolymph of adult stage $(18,45$ and $72 \mathrm{kDa}$ ). This inhibition in hemolymph protein of $S$. gregaria may be due to the destructive effect of neem on cerebral neurosecretory in the brain which are responsible for protein secretion. It may be also due to insufficient stimulation of neurosecretory activity which leads to reduction in protein amount in hemolymph that required for oocytes development according to ${ }^{[22]}$. In addition, ${ }^{[23]}$ stated that reduction in hemolymph proteins in adult $S$. gregaria treated with consult (Chitin-synthesis inhibitor, Hexaflumuron) may reflect the reduction in the capacity of the protein synthesis, and this decrease in hemolymph proteins which resulted in the inhibition of oogenesis and ovarian development lead to sterility of adult insect.

From the previous results it was concluded that azadirachtin may affect on adult $S$. gregaria protein profile, which agreed with ${ }^{[21]}$, they suggested that azadirachtin interfered with protein synthesis in desert locust. Azadirachtin has a potential to be used as biopesticides in insect pest management ${ }^{[24]}$.

Table 1: Hemolymph protein monitoring of treated and control adults S.gregaria expressed as molecular weight. $\mathrm{M}=$ wide range protein marker $(150,120,100,85,70,60,50,40,30,25$ and $15 \mathrm{kDa})$. Lane $\mathrm{C}=$ control. Lanes 1,2 and $3=$ treated hemolymph protein patterns with $(7.5,15$ and $30 \mu \mathrm{g} / \mathrm{g}$ body weight of azadirachtin), respectively.

\begin{tabular}{|c|c|c|c|c|c|}
\hline Lanes: & Marker & Lane C & Lane 1 & Lane 2 & Lane 3 \\
\hline Rows & (mol.w.) & (mol.w.) & (mol.w.) & (mol.w.) & (mol.w.) \\
\hline 1 & 150 & 140 & 140 & & \\
\hline 2 & 120 & & 120 & & 120 \\
\hline 3 & 100 & 108.57 & 108.57 & & 108.56 \\
\hline 4 & 85 & 86.875 & & & \\
\hline 5 & 70 & & 72 & 72 & 72 \\
\hline 6 & & 65.455 & 65.445 & 65.44 & 65.273 \\
\hline 7 & 60 & & & & \\
\hline 8 & & 58 & 58 & 58 & 58 \\
\hline 9 & 50 & & & & \\
\hline 10 & & & 45 & 45 & 45 \\
\hline 11 & 40 & & & & \\
\hline \multicolumn{6}{|l|}{12} \\
\hline 13 & 30 & & & & \\
\hline \multicolumn{6}{|l|}{14} \\
\hline 15 & 25 & 25.455 & 25.409 & & 25.4 \\
\hline 16 & & 23.6 & 23.667 & 23.6 & \\
\hline 17 & 20 & & & & \\
\hline 18 & & & 18.571 & 18 & 18.095 \\
\hline 19 & & 16.667 & & 16.6 & 16.605 \\
\hline 20 & 15 & 15 & 15 & & \\
\hline 21 & 10 & 11 & & 11 & 11.1 \\
\hline
\end{tabular}


Table 2: Amount percentage (amount \%) and relative fragmentation of hemolymph protein fractions of treated and control adults S.gregaria. $\mathrm{M}=$ wide range protein marker $(150,120,100,85,70,60,50,40,30,25$ and 15 $\mathrm{kDa})$. Lane $\mathrm{C}=$ control. Lanes 1,2 and 3 = treated hemolymph protein patterns with $(7.5,15$ and $30 \mu \mathrm{g} / \mathrm{g}$ body weight of azadirachtin), respectively.

\begin{tabular}{|c|c|c|c|c|c|}
\hline Lanes: & Marker & Lane $C$ & Lane 1 & Lane 2 & Lane 3 \\
\hline Rows & $\underset{\%}{\text { Amount }}$ & $\underset{\%}{\text { Amount }}$ & $\underset{\%}{\text { Amount }}$ & $\underset{\%}{\text { Amount }}$ & $\underset{\%}{\operatorname{Amount}}$ \\
\hline r1 & 1.0797 & 2.6875 & 3.145 & & \\
\hline r2 & 1.8834 & & 5.5564 & & 4.3564 \\
\hline r3 & 1.7361 & 1.4565 & 9.3562 & & 12.483 \\
\hline r4 & 1.7192 & 1.1042 & & & \\
\hline r5 & 2.896 & & 11.185 & 7.3107 & 10.653 \\
\hline r6 & & 24.968 & 7.6281 & 8.943 & 20.941 \\
\hline r7 & 3.1986 & & & & \\
\hline r8 & & 4.8695 & 13.539 & 14.578 & 15.149 \\
\hline r9 & 4.0487 & & & & \\
\hline r10 & & & 7.054 & 7.9215 & 9.7226 \\
\hline r11 & 11.613 & & & & \\
\hline \multicolumn{6}{|l|}{ r12 } \\
\hline r13 & 6.229 & & & & \\
\hline \multicolumn{6}{|l|}{ r14 } \\
\hline r15 & 6.626 & 3.7006 & 1.8996 & & 1.4747 \\
\hline r16 & & 5.1355 & 1.9293 & 4.358 & \\
\hline r17 & 9.2321 & & & & \\
\hline r18 & & & 0.59991 & 1.2684 & 2.53 \\
\hline r19 & & 12.339 & & 2.1149 & 0.56544 \\
\hline r20 & 13.318 & 4.2239 & 1.8741 & & \\
\hline r21 & 10.5 & 6.2412 & & 4.6883 & 1.2716 \\
\hline Sum & 74.08 & 81.831 & 73.88 & 75.172 & 74.981 \\
\hline In Lane & 100 & 100 & 100 & 100 & 100 \\
\hline
\end{tabular}

\section{References}

1) Schmutterer, H. (1990). Properties and potential of natural pesticides from the neem tree, Azadirachta indica. Annu. Rev. Entomol., 35: 271-297.

2) Senthil Nathan, S., Kalaivani, K., Murugan, K. and Chung, P. G. (2005). The toxicity and physiological effect of neem limonids on Cnaphalocrocis medinalis (Guenée) the rice leaffolder. Pesticide Biochem. Physiol., 81: 113-122.

3) Mordue, A. J. and Blackwell, A. (1993). Azadirachtin: an update. Journal of Insect Physiology, 39: 903-924.

4) Al-Fifi, Z. I., (2006). Molting inhibitory and lethal effect of azadirachtin on the desert locust, Schistocerca gregaria (Forskal). J. Entomol. 3 (4): 312-318.
5) Vardhini, D., Mary, A., Raja, S. and Renuka, P. (1997). Influence of azadirachtin on the ecdysonecontrolled developmental processes in the stored grain pest, Tribolium confusum (Duval). Nigerian J. Entomol. 14/15: 90-98.

6) Chander, H., Ahuja, D. K., Nagender, A. and Berry, S. K., (2000). Repellency of different plants extracts and commercial formulations used as prophylactic sprays to protect bagged grain against Tribolium castaneum- a field study. J. Food Sci. Tech. 37(6): 582-585.

7) Lohra, Y., Singhvi P.M. and Pamwar M. (2001). Effect of certain plant extracts on oviposition of rustred flour beetle, Tribolium castaneum Herbst: infesting stored jowar. J. Appl. Zool. Res. 12(1): 6770. 
8) Ahmed, S., Wilkins, R. and Mantle, D. (2002). Comparative effect of various insecticides on intracellular proteases in an insecticide-resistant and susceptible strains of Musca domestica L. J. Biol. Sci. 2, 183-185.

9) Isman, M. B. (1993). Growth inhibitory and antifeedant effects of azadirachtin on six noctuids of regional economic importance. Pesticide Sci. 38: 57-63.

10) Martinez, S. S. and Van Emden, H. F. (1999). Sublethal concentrations of azadirachtin affect food intake, conversion efficiency and feeding behaviour of Spodoptera littoralis (Boisduval) (Lepidoptera: Noctuidae). B. Entomol. Res. 89: 65-71.

11) Steedman, A. (1990). Locust hand book, natural resources institute, Cathan. U. K.

12) Uvarov, B. P. (1921). XVII. Grasshoppers (Orthoptera, Acrididae) from Northern Nigeria. $B$. $P$. UVAROV Bull. Entomol. Res., 12: 13 -163.

13) Roffy, J. and Popov, G. B., (1968). Environmental and behavioral processes in a desert locust outbreak. Nature, 219: 446-450.

14) Paranacama, P. A., Connolly, J. D. and Strang, R. H. C. (2004). Azadirachtin effects on protein biosynthesized in fat body, haemolymph, ovary and midgut of locust Schistocerca gregaria. J. Natn. Sci. foundation, Serilanka 32 (1\&2): 13-28.

15) Rembold, H., (1984). Secondary plant products in insect control with special reference to azadirachtins P. 481-491. In W. Engels,(Ed). Advances in invertebrate production 3. Elsevier, Amesterdam.

16) Forster, H., Czoppelt, Ch., Rao P. J., and Sieberk, P. (1988). The azadirachtins, a group of insect growth regulators from neem trees. Proceeding of the $2^{\text {nd }}$ international neem conference.
Rausschholhausen: 153-162.

17) Laemmli, U. K. (1970). Cleavage of structural proteins during the assembly of the head of bacteriophage T4. Nature 227, 680-685.

18) Cohen, E. (2010). Chitin biochemistry: Synthesis, hydrolysis and inhibition. Advances in Insect Physiology. 38: 5-74.

19) Sugumaran, M. (2010). Chemistry of cuticular sclerotization. Advances in insect Physiology. 39: 151-209.

20) Carlisle, J. A., Oughton, B. and Ampleford, E. (1987). Feeding causes the appearance of a factor in the haemolymph that stimulates protein synthesis. J. Insect Physiol., 33:493-499.

21) Annadurai, R. S. and Rembold, H. (1993). Azadirachtin A modulates the tissue specific 2 D polypeptide patterns of the desert locust, Schistocerca gregaria. Natur wissen scafien 80, $127-$ 130.

22) Lusis, O. (1963). The histology and histochemistry of development and resorption in the terminal oocytes of the desert locust, Schistocerca gregaria. Quart J. Micr. Sci., 104:57-68.

23) Reda, F. A. Mona, I. M., El-Gammal, M. and Noura, M. M. (2009). Biochemical changes of the Chitin-synthesis inhibitor, Hexaflumuron (Consult) compound on the desert locust, Schistocerca gregaria (Forskal). Egypt. Acad. J. biolog. Sci., 1 (1): $59-68$.

24) Amtul, J. S. (2014). Azadirachta indica derived compounds as inhibitors of digestive alpha-amylase in insect pests: Potential bio-pesticides in insect pest management. European J. Experment. Biol. 4(1): 259-264. 